University of Nebraska - Lincoln

DigitalCommons@University of Nebraska - Lincoln

Faculty Papers and Publications in Animal

Science

Animal Science Department

2001

\title{
Locomotor activity, core body temperature, and circadian rhythms in mice selected for high or low heat loss
}

\author{
M. R. Mousel \\ University of Nebraska-Lincoln \\ Walter W. Stroup \\ University of Nebraska-Lincoln, wstroup1@unl.edu \\ Merlyn K. Nielsen \\ University of Nebraska-Lincoln, mnielsen1@unl.edu
}

Follow this and additional works at: https://digitalcommons.unl.edu/animalscifacpub

Part of the Animal Sciences Commons

Mousel, M. R.; Stroup, Walter W.; and Nielsen, Merlyn K., "Locomotor activity, core body temperature, and circadian rhythms in mice selected for high or low heat loss" (2001). Faculty Papers and Publications in Animal Science. 497.

https://digitalcommons.unl.edu/animalscifacpub/497

This Article is brought to you for free and open access by the Animal Science Department at DigitalCommons@University of Nebraska - Lincoln. It has been accepted for inclusion in Faculty Papers and Publications in Animal Science by an authorized administrator of DigitalCommons@University of Nebraska - Lincoln. 


\title{
Locomotor activity, core body temperature, and circadian rhythms in mice selected for high or low heat loss ${ }^{1}$
}

\author{
M. R. Mousel ${ }^{*, 2}$, W. W. Stroup $\dagger$, and M. K. Nielsen $*, 3$ \\ *Department of Animal Science and †Department of Biometry, University of Nebraska, Lincoln 68583-0908
}

\begin{abstract}
Daily locomotor activity, core body temperature, and their circadian rhythms were measured in lines of mice selected for high (MH) or low (ML) heat loss and unselected controls (MC). Lines were created by selecting for 16 generations in each of three replicates. Collection of locomotor activity and core temperature data spanned Generations 20 and 21 for a total of 352 mice. Physical activity and core body temperature data were accumulated using implanted transmitters and continuous automated collection. Measurement for each animal was for $3 \mathrm{~d}$. Activity was recorded for each half hour and then averaged for the day; temperature was averaged daily; circadian rhythm was expressed in 12-h (light vs dark) or 6-h periods as well as by fitting cyclic models. Activity means were transformed to log base 2 to lessen heterogeneity of variance within lines. Heat loss for a 15 -h period beginning at 1630 and feed intake for $7 \mathrm{~d}$ were measured on 74 additional mice in order to estimate the relationship between locomotor activity and heat loss or feed intake. Selection lines were different $(P<0.01)$ for both locomotor activity and core body temperature. Differences were due to
\end{abstract}

selection (MH-ML, $P<0.01$ ), and there was no evidence of asymmetry of response $(P>0.38)$. Retransformed from $\log$ base 2 to the scale of measurement, mean activity counts were 308,210 , and 150 for $\mathrm{MH}, \mathrm{MC}$, and $\mathrm{ML}$, respectively. Mean core temperatures were $37.2,36.9$, and $36.7^{\circ} \mathrm{C}$ for $\mathrm{MH}, \mathrm{MC}$, and $\mathrm{ML}(P<0.01)$, respectively. Females had greater physical activity $(P$ $<0.01)$ and body temperature $(P<0.01)$ than males. There was no evidence of a sex $\times$ selection criterion interaction for either activity or temperature $(P>0.20)$. Overall phenotypic correlation between body temperature and log base 2 activity was $0.43(P<0.01)$. Periods during the day were different for both 12 - and 6-h analyses $(P<0.01)$, but there were no period $\times$ selection criterion interactions $(P>0.1)$ for physical activity or body temperature. More sensitive cyclic models revealed significant $(P<0.01) 24-, 12-, 8$-, and 6 -h cycles that differed $(P<0.01)$ among lines. Estimated differences between $\mathrm{MH}$ and ML mice in feed intake and heat loss due to locomotor activity were 36 and $11.5 \%$, respectively. Variation in activity thus contributed to variation in feed intake.

Key Words: Body Temperature, Circadian Rhythm, Feed Intake, Heat Loss, Mice, Physical Activity

(C2001 American Society of Animal Science. All rights reserved.

J. Anim. Sci. 2001. 79:861-868

\section{Introduction}

Livestock producers are continually looking for ways to reduce their production costs. There is considerable variation in the amount of feed required for animals to reach optimal slaughter weight. A large portion of this variance is due to variation in energy used for maintenance. Milligan (1985) hypothesized that reduction in maintenance energy is an avenue for improvement in

\footnotetext{
${ }^{1}$ Published as paper no. 12726, Journal Ser., Nebraska Agric. Res. Div., Univ. of Nebraska, Lincoln 68583-0908.

${ }^{2}$ Current address: College of Veterinary Science, University of Kentucky, Lexington 40546.

${ }^{3}$ Correspondence: A218 Animal Science (phone: (402)472-6406; fax: (402)472-6362; E- mail: mnielsen1@unl.edu).

Received July 10, 2000.

Accepted December 8, 2000.
}

energetic efficiency. Locomotor activity requires energy, but precisely how that is related to maintenance requirements and thus feed intake is not well known.

Activity plays a significant role in the energy expenditure of cattle (Nienaber et al., 1985), swine (Halter et al., 1980; Verstegen et al., 1982; Henken et al., 1991), poultry (MacLeod et al., 1982; Luiting et al.,1991), and mice (Daucey, 1986; Moruppa, 1990; Bunger et al., 1998). Activity is positively correlated with heat loss (Moruppa, 1990), feed intake (Voisinet et al., 1997), and core body temperature (Gordon, 1993). Genetic selection of mice in our laboratory (Nielsen et al., 1997a,b) resulted in significant changes in heat loss and feed intake. The objective of this research was to determine whether there are differences in the activity, core body temperature, and circadian rhythms of mice selected for high and low heat loss. An additional objective, if differences in activity were detected, was to determine what proportion of the differences between selection 
lines in heat loss and feed intake was due to activity difference.

\section{Materials and Methods}

Experimental Animals. The lines of mice used in this experiment were previously described by Nielsen et al. (1997a,b). Selection had been practiced for high (MH) and low (ML) heat loss per unit of metabolic size per day $\left(\mathrm{kcal} / \mathrm{kg}^{0.75} / \mathrm{d}\right)$, with heat loss measured in direct calorimeters. In addition, unselected control (MC) mice were also produced. All three selection criteria $(\mathrm{MH}$, $\mathrm{ML}$, and MC) were practiced in each of three independent replicates for a total of nine lines. After 16 generations, selection ceased and the lines were maintained for studies of various characteristics.

For this study, mice were housed in plastic cages with wire grid lids, set up initially as five of one sex per cage, and all of the same selection line. Only one mouse was measured per cage per time period. After its measurement was completed, the mouse was removed from the cage. To maintain normal animal interaction, there were at least two mice in a cage during measurement. Mice were given ad libitum access to water and a rodent block diet (Teklad diet 8604: $24 \%$ crude protein, $4 \%$ crude fat, $4.5 \%$ crude fiber, and $3.93 \mathrm{kcal} / \mathrm{g}$ gross energy). Ambient conditions of the laboratory were $12 \mathrm{~h}$ lights on and $12 \mathrm{~h}$ lights off, at a constant temperature of $23^{\circ} \mathrm{C}$.

Mice from all three replicates spanning Generations 20 and 21, and the three selection criteria, $\mathrm{MH}, \mathrm{ML}$, and MC, were evaluated for a total of 352 mice. Mice ranged in age from 13 to $23 \mathrm{wk}$ at measurement. Collection of data began September, 1996, and concluded May, 1997. All procedures in the experimental protocol were approved by the University of Nebraska-Lincoln Animal Care and Use Committee.

Measurement of Traits. An Automated Data Acquisition System was purchased from the Mini-Mitter Company (Sunriver, OR) for collection of locomotor activity and body temperature data. With the mice under general anesthesia using inhaled methoxyflurane, transmitters were implanted intraperitoneally. Each implanted mouse was returned to its cage with its cage mates, and the cage was placed over a receiver plate that measured activity by monitoring transmitter location and temperature by the frequency of the radio pulse (greater pulse frequency equates to higher temperature). The data were then sent to a multiplexor that organized the collection process and relayed the information to a computer where radio pulses were converted to degrees Celsius. Initially there were six receiver plates; however, two more plates were added during the last third of the study, enabling simultaneous measurement of eight animals.

For each animal, data were collected for $3 \mathrm{~d}$ following a 1-d recovery period. This timing protocol was determined from a preliminary study using 72 mice. In the preliminary study, mice were measured for an average of $7 \mathrm{~d}$. Due to heterogeneity of variances between different selection lines, activity data were transformed to the $\log$ base 2 . Animal and day $\times$ animal variances were estimated and used to compare the expected variance of a mean of a group of animals using either 4-d or 7-d periods, i.e., data collected for 3 or $6 \mathrm{~d}$, respectively. The following equation for the variance of the mean of a animals measured for d days (3 or 6): $\left(\sigma_{\text {animal }}^{2} / \mathrm{a}\right)+$ $\left[\sigma_{\text {day/animal }}^{2}(\mathrm{a} \cdot \mathrm{d})\right]$, where $\mathrm{a}=$ number of animals and $\mathrm{d}$ $=$ number of days.

By fixing the amount of time that data could be collected, one could measure 4/7 as many animals using 7 -d periods as 4 -d periods. The estimates of variances were $\sigma_{\text {animal }}^{2}=0.20$ and $\sigma_{\text {day/animal }}^{2}=0.08$. The expected variance of the mean was smaller, given the same amount of time invested, if we measured more animals, committing $4 \mathrm{~d}$ for each animal. Thus, the protocol used for measurement was to collect data for $72 \mathrm{~h}(3 \mathrm{~d})$ beginning and ending at 1000.

For the second objective, to assess the proportion of differences between selection lines explained by differences in activity, 74 additional mice were placed through the same procedure above, and then feed intake and heat loss measurements were also recorded. Feed intake was measured for $7 \mathrm{~d}$ using ground feed placed in a feeder that allowed minimal wastage. Feed consumed was expressed as grams per metabolic weight per day $\left(\mathrm{g} / \mathrm{kg}^{0.75} / \mathrm{d}\right)$. Heat loss $\left(\mathrm{kcal} / \mathrm{kg}^{0.75} / \mathrm{d}\right)$ was measured according to Nielsen et al. (1997b).

Statistical Analysis. Activity and core body temperature were analyzed as daily means for the 30-min measurements. Effects of selection criterion, sex, and day were evaluated using a model that included replicate as a random effect and selection criterion $\mathrm{MH}, \mathrm{ML}$, or MC), sex, and day as fixed effects. Replicate $\times$ selection criterion was used as the error term to test the effects of selection criteria. In addition, orthogonal contrasts of the selection criteria means (MH - ML: to test selection response, and $[(\mathrm{MH}+\mathrm{ML}) / 2]-\mathrm{MC}$ : to test for asymmetry of response) were tested with replicate $x$ selection criterion as the error term. Sex and selection criterion $\times$ sex interaction were tested with the splitplot error (replicate $\times$ sex), and day was tested with the residual error. The correlation of activity and temperature and the pooled within selection criterion, sex correlations were calculated.

To study circadian rhythms, two approaches were used. First, data were expressed as the 30 -min means in 12-h (light/dark) or 6-h periods. Effects of selection criterion and period and their interaction as fixed effects were evaluated in a model that also included replicate and its interactions as random effects. Selection criterion was tested as described above, and period was tested with replicate $\times$ period as the error term.

The second approach to study circadian rhythms used a Fourier series model. Using the 30-min data over the $3 \mathrm{~d}$, a repeated measures model was fitted that included time effects due to the 30-min observations in addition to the fixed effects of selection criterion and the random 
effects of replicate and the interaction of replicate and selection criterion. The time effects were decomposed into their Fourier series spectra in order to estimate the components of cyclic variation over time. The Fourier components took the form

$$
\Sigma\left[\beta_{\operatorname{lm}} \sin \left(2 \pi \mathrm{i} / \mathrm{s}_{\mathrm{m}}\right)+\beta_{2 \mathrm{~m}} \cos \left(2 \pi \mathrm{i} / \mathrm{s}_{\mathrm{m}}\right)\right]
$$

where $\mathrm{m}$ denotes the different cycles, $\mathrm{i}$ denotes the observation (from 1 to 144 for the 30-min observations for $3 \mathrm{~d}$ ), and s denotes the length of the periodicity for the $\mathrm{m}^{\text {th }}$ length of cycle.

Preliminary model fits showed that 24-h, 12-h, 8-h, and 6 -h cycles, summed together as above, were all important in describing the cyclicity observed. Thus, these four cycles $(\mathrm{m}=4)$ were fitted and checked for interaction with selection criterion. Orthogonal contrasts using the Fourier sine and cosine components were defined for each periodicity considered important. Contrasts were then defined to interact them with those previously defined to compare the selection criteria. These interaction definitions test whether cyclic variation is the same for all selection criteria and, if there are differences, where those differences occur. These were tested with standard $F$-test for contrasts.

For the second objective, heat loss $\left(\mathrm{kcal} / \mathrm{kg}^{0.75} / \mathrm{d}\right)$ and feed intake $\left(\mathrm{g} / \mathrm{kg}^{0.75} / \mathrm{d}\right)$ were fitted to an initial fixed model of line, sex, contemporary group, the regression on log base 2 activity, plus two- and three-way interactions of the regression with line, sex, and line $\times$ sex. The model was reduced to delete nonsignificant effects. The final model for heat loss included line, sex, contemporary group, and the regression on log base 2 activity. The final model for feed intake only included line, sex, and the regression on log base 2 activity. The regression coefficients times the difference between the lines in $\log$ base 2 activity estimated the amount of heat or feed differences between selection lines due to their activity difference.

\section{Results and Discussion}

Locomotor Activity. The least-squares means from the log base 2 analysis, both as a log and retransformed, for selection criterion, sex, and day are shown in Table 1 . Because data were transformed to log base 2, standard errors could not be calculated for the retransformed means. Confidence intervals (95\%) were calculated and then retransformed to the scale of measurement.

Differences between selection criteria, sexes, and days were significant $(P<0.03)$ for locomotor activity. The mean for MH was different from the mean for ML ( $P$ $<0.01)$. There was no evidence of asymmetry of selection response $(P>0.37)$. There also was no evidence of a sex $\times$ selection criterion interaction $(P>0.32)$. A day $\times$ selection criterion interaction was possibly important $(P<0.10)$. However, with the removal of $d 1$, this interaction was no longer significant $(P>0.75)$.
Mice of line $\mathrm{MH}$ were more active than were $\mathrm{MC}$ and ML mice, with ML mice having the lowest activity of the three. In fact, $\mathrm{MH}$ mice averaged twice the activity counts as ML mice. Females were more active than males. Few studies evaluated both sexes for activity level, and of those that did, even fewer included it as an effect in their model. Moruppa (1990) found that male mice were more active than females at young (3to 4 -wk) and old (10- to 11-wk) ages. This is contrary to our findings, but Moruppa (1990) measured for only a 3-h period during the lighted part of the day. However, cattle data reported by Voisinet et al. (1997) agree with this study; heifers were more active (temperamental) than steers.

Rauw et al. (2000) reported differences in locomotor activity between mice of a high litter size selection line and a control line. Only females were observed, and they were measured during lighted hours using shortterm open field and maze protocols. Litter size born was double (21 pups) in the selected line compared with the control (10 pups), and residual feed intake was higher in the selected line than the control. The present results are consistent with those of Rauw et al. (2000) because the $\mathrm{MH}$ mice exceed the ML mice significantly in feed intake (not associated with body size or growth rate) and in litter size born.

Other mouse strains have been identified that differ in activity levels. Dauncey (1986) found that C57BL ob/ $o b$ mice were less active compared with lean C57BL 6/ 6 mice. Mice, selected for appetite or maintenance were found to have different activity level by Moruppa et al. (1990) during daylight hours. Differences in daily amplitude oscillations of locomotor activity were found in C57BL/6 compared with BALB/cBy strains of mice (Toth et al., 1995). In White Leghorn laying hens selected for extremes in residual feed consumption (Luiting et al., 1991), high-intake hens spend $28 \%$ of daily heat production on activity whereas low-intake hens spend only $18 \%$ of heat production on activity. The above findings and those of this study demonstrate that there is genetic variation in locomotor activity.

Activity increased with each day following the 1-d adjustment period after surgery. Although the preliminary study indicated that a 1-d adjustment period was optimal for allocating time and resources, $\mathrm{d} 1$ was different from both $d 2$ and $d 3$. Removal of $d 1$ from the data eliminated the day effect $(P>0.35)$. Other studies using telemetry (Honma and Hiroshige, 1978; Strickland et al., 1998) allowed for a longer recovery period $(7 \mathrm{~d})$.

The correlation of activity with core body temperature, unadjusted for any effects of selection criterion, replicate, sex, or day was $0.43(P<0.05)$. Honma and Hiroshige (1978) calculated correlations of physical activity and body temperature for light and dark periods as 0.25 to 0.802 in rats. However, the pooled correlation calculated within sex $\times$ selection criterion subclasses was not different from zero. Because the mice in this project were selected for 16 generations for heat loss, they were genetically different. With overall and sub- 
Table 1. Locomotor activity ${ }^{\mathrm{a}}$ and core body temperature least-squares means for different selection criteria applied, sexes, and days

\begin{tabular}{|c|c|c|c|c|c|c|}
\hline \multirow[b]{2}{*}{ Item } & \multicolumn{2}{|c|}{ Log base 2 activity } & \multicolumn{2}{|c|}{ Retransformed activity $^{\mathrm{b}}$} & \multicolumn{2}{|c|}{ Body temperature, ${ }^{\circ} \mathrm{C}$} \\
\hline & Mean & $\mathrm{SE}$ & Mean & $95 \% \mathrm{CI}$ & Mean & $\mathrm{SE}$ \\
\hline \multicolumn{7}{|c|}{ Selection criterion ${ }^{\mathrm{c}}$} \\
\hline $\mathrm{MH}$ & 8.27 & 0.15 & 308 & 278-342 & 37.19 & 0.06 \\
\hline $\mathrm{MC}$ & 7.72 & 0.15 & 210 & 189-233 & 36.94 & 0.06 \\
\hline $\mathrm{ML}$ & 7.23 & 0.15 & 150 & $136-167$ & 36.68 & 0.06 \\
\hline \multicolumn{7}{|l|}{ Sex } \\
\hline Male & 7.53 & 0.10 & 185 & $173-199$ & 36.86 & 0.03 \\
\hline Female & 7.94 & 0.10 & 246 & 229-264 & 37.01 & 0.03 \\
\hline \multicolumn{7}{|l|}{ Day $^{\mathrm{d}}$} \\
\hline 1 & 7.53 & 0.05 & 184 & 179-190 & 36.87 & 0.03 \\
\hline 2 & 7.80 & 0.05 & 223 & 216230 & 36.95 & 0.03 \\
\hline 3 & 7.89 & 0.05 & 237 & $230-245$ & 36.98 & 0.03 \\
\hline
\end{tabular}

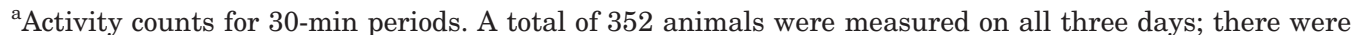
$113 \mathrm{MH}, 118 \mathrm{MC}$, and $121 \mathrm{ML}$; for the two sexes, there were 171 males and 181 females.

${ }^{\mathrm{b}}$ Retransformed from log base 2 data; $95 \%$ confidence interval (CI) computed using log base 2 mean and $\mathrm{SE}$, then retransformed.

${ }^{\mathrm{c}} \mathrm{MH}=$ High heat loss, $\mathrm{MC}=$ Control, and $\mathrm{ML}=$ Low heat loss.

${ }^{\mathrm{d}}$ Day of data collection, initiated $1 \mathrm{~d}$ following transmitter implantation.

class correlations being different, genetic and phenotypic relationships between activity and temperature are different.

These results indicate that unintentional selection for activity occurred when these mice were selected for heat loss. Therefore, selection for low heat loss, and thus low maintenance requirement, also results in low activity. This is supported by a swine study by Henken et al. (1991). If the reverse were true, animals selected for low activity would also have low maintenance requirements and reduce the overall production costs. However, there appears to be an undesirable relationship between low maintenance requirements/low activity and greater fat percentage. Nielsen et al. (1997a) reported that ML had higher fat percentages than $\mathrm{MH}$.

Core Body Temperature. Core body temperature means for criterion, sex, and day also appear in Table 1. Body temperatures were within the accepted range for mice (Gordon, 1993). Line, sex, and day were different $(P<0.01)$. Again, day differences were due to the first day being lower than the second and third days. Removal of $\mathrm{d} 1$ reduced the day effect but did not eliminate it $(P<0.04)$. Mice of line MH were different from those of line $\mathrm{ML}(P<0.01)$; they averaged $0.51^{\circ} \mathrm{C}$ higher in temperature. There was no evidence of asymmetry of selection response $(P>0.57)$ or of a day $\times$ selection criterion interaction $(P>0.69)$.

Males had lower average core temperatures than females by $0.16^{\circ} \mathrm{C}(P<0.01)$. Temperature differences due to sex are found in most mammalian species (Gordon, 1993) and are especially well studied in rodents (McDonald et al., 1989; Yanase et al., 1989). The action of steroid sex hormones can have an impact on the thermoregulatory processes (Gordon, 1993). These differences are partially due to the estrous cycle (Yanase et al., 1989). The body temperature of female rats is $0.5^{\circ} \mathrm{C}$ higher than males at night during estrus. These differences could not be detected during the day. However, in this study, female mice would have been sampled during the entire estrous cycle, thus reducing the skewing of data due to estrus. It is also possible that the mice used in this study were not cycling, as ovulation is stimulated by copulation and female mice caged together tend not to cycle.

Sexes also differ in heat production; females are reported to have higher heat loss at normal room temperature (Castella and Alemany, 1985; Moody et al., 1997). In cold environments, core body temperatures are the same in male and female rats, suggesting that insulation or other factors allow females to thermoregulate more efficiently (Doi and Kuroshima, 1982) or that females overheat more readily.

These mice were also unintentionally selected for core body temperature when selected for heat loss. Refinetti and Menaker (1992) found evidence to suggest that variation in heat loss is the main factor in variation of core body temperature. Thus, it would be reasonable for core temperature to change when selecting for heat loss.

Circadian Rhythm. The least-squares means for 12$\mathrm{h}$ and 6 -h activity periods appear in Table 2. Periods were different for both the 12-h and 6-h analyses $(P$ $<0.01$ ). Evidence suggests a weak period $\times$ selection criterion interaction $(P>0.09)$ for 12 -h periods. This was due to a greater magnitude of difference between $\mathrm{MH}$ and ML during dark (log base 2 activity: $\mathrm{MH} 8.49$, ML 7.29) compared with during light (MH 7.74, ML 6.72). There was no period $\times$ selection criterion interaction for 6 -h periods. The 6 -h analysis indicated period $\times$ sex $(P<0.01)$, period $\times$ day $(P<0.01)$, and period $\times$ sex $\times$ day $(P<0.01)$ interactions. The day interaction effects are due to the differences of scale in day means.

Least-squares means of core body temperature for 12-h and 6-h periods also appear in Table 2. Period was different $(P<0.01)$ in both analyses. There was not a 
period $\times$ selection criterion interaction for either length of period $(P>0.2)$. Data for the 6 -h study indicated period $\times$ day $(P<0.01)$, period $\times \operatorname{sex}(P<0.01)$, and a suggestive period $\times$ day $\times \operatorname{sex}(P<0.07)$ interactions. The 12 -h data had only a period $\times$ day interaction $(P$ $<0.01)$.

Locomotor activity and body temperature 12 -h means followed the same trend, with the light hours having low activity and temperature and the dark hours having elevated activity and temperature. Because mice are nocturnal, this was expected.

In the 6-h data, different rhythms occurred for physical activity and body temperature. Mouse activity was moderate at the beginning of the light period; during the second half of the light period, activity decreased. As anticipated, activity was elevated during the first half of the dark period but fell to a moderate level during the second half of the dark period. The difference in activity in the 6-h analysis was due to the second half of the light period and the first half of the dark period. Animal temperatures followed a somewhat different cycle. Temperature began at an intermediate level and then increased during the second half of the lighted period. During the dark period, temperature increased slightly from the second lighted period then dropped to a moderate level during the second dark period. These data support the theory that different pathways are responsible for activity and temperature rhythms. This is especially evident during the second half of the lighted period when mice had low activity but high core body temperatures.

Figure 1 contains 30-min mean physical activity for the 3-d period beginning at 1000 for all three selection criteria. Figure 2 shows 30 -min mean core body temperature beginning at 1000 for $3 \mathrm{~d}$. These illustrate the differences between the lines over the $3 \mathrm{~d}$.

The Fourier series model with combined four (24-, $12-, 8-$, and 6-h) periodicities was used with both the untransformed and log base 2 transformed activity data plus the core body temperature data. Similar patterns

Table 2. Locomotor activity and core body temperature least-squares means for 12 -h and 6-h daily periods

\begin{tabular}{|c|c|c|c|c|}
\hline \multirow[b]{2}{*}{ Item } & \multicolumn{2}{|c|}{ Locomotor activity $^{\mathrm{a}}$} & \multicolumn{2}{|c|}{ Core Body temperature, ${ }^{\circ} \mathrm{C}$} \\
\hline & Mean & $95 \% \mathrm{CI}^{\mathrm{b}}$ & Mean & $\mathrm{SE}$ \\
\hline \multicolumn{5}{|c|}{ 12-h period } \\
\hline Light & 150 & $149-152$ & 36.8 & 0.01 \\
\hline Dark & 239 & $237-241$ & 37.0 & 0.01 \\
\hline \multicolumn{5}{|c|}{ 6-h period } \\
\hline Light 1 & 170 & $166-173$ & 36.4 & 0.02 \\
\hline Light 2 & 115 & $113-118$ & 37.1 & 0.02 \\
\hline Dark 1 & 290 & $284-296$ & 37.2 & 0.02 \\
\hline Dark 2 & 168 & $164-171$ & 36.9 & 0.02 \\
\hline
\end{tabular}

${ }^{\text {a}}$ Retransformed from analysis of log base 2 data; average of 30 min periods. A total of 318 animals contributed data for both 12 -h and 6 -h periods.

${ }^{\mathrm{b}}$ Confidence interval calculated using $\log$ base 2 mean and SE, then retransformed. were obtained with each variable. For log base 2 activity, the contrasts of $\mathrm{MH}-\mathrm{ML}$ and $[(\mathrm{MH}+\mathrm{ML}) / 2]-$ MC interacted significantly $(P<0.03$ for 12 -h periodicity and $\mathrm{P}<0.0001$ for the others) for all four cycle lengths. For untransformed activity, the contrasts interacted significantly $(P<0.005)$ for all except $[(\mathrm{MH}+$ $\mathrm{ML}) / 2$ ] - MC for 24-h and 6-h cycles. For core body temperature, contrast $[(\mathrm{MH}+\mathrm{ML}) / 2]-\mathrm{MC}$ was not significant $(P>0.20)$ for 6 -h cycles, and, with the exception of contrast MH - ML for 12 -h cycles $(P<0.03)$, all were highly significant $(P<0.0001)$.

Twenty-four-hour cycles (the sum of the four periodicities for MH, ML, and MC mice), plotted using the coefficients estimated from the models, are shown for untransformed locomotor activity in Figure 3 and for core body temperature in Figure 4. The patterns of physical activity and body temperature were fairly similar demonstrating that physical activity generates heat that is not dissipated quickly. The rather complicated 24 -h cycle can only be described with four periodicities. Besides having clearly different peak physical activity and body temperature levels, the patterns of peaks and valleys also differed. All mice had two peaks during the dark 12-h period and one distinct peak during the light 12$\mathrm{h}$ period. The ML mice reached their peak activities ahead of the $\mathrm{MH}$ and $\mathrm{MC}$ mice, and the ML mice reached their peak body temperature during the light period ahead of the $\mathrm{MH}$ and $\mathrm{MC}$ mice.

A human study by Krauchi and Wirz-Justice (1994) found that the circadian rhythm of heat production precedes rectal temperature rhythm, thus indicating a phase delay of heat loss with respect to core temperature. Another human study found a $17 \%$ variance in individual core temperature rhythms that was not explained by known endogenous or exogenous components (Hiddinga et al., 1997). In other species, amplitude of core temperature rhythms was found to be different between different strains of mice. Strain $\mathrm{C} 3 \mathrm{H}$ mice had a higher ampliture $\left(2.4^{\circ} \mathrm{C}\right)$ compared with C57BL mice $\left(1.8^{\circ} \mathrm{C}\right)$ (Connolly and Lynch, 1983). In another report, the CBA strain of mice had a higher amplitude $\left(1.4^{\circ} \mathrm{C}\right)$ compared with $\mathrm{N} 2 \mathrm{~B}\left(1.1^{\circ} \mathrm{C}\right)$ and $\mathrm{C} 3 \mathrm{H}$ $\left(0.4^{\circ} \mathrm{C}\right)$ mice (Yunis et al., 1974). Golden-mantled ground squirrels also displayed a range in amplitude of core temperature rhythm that averaged 35 to $39^{\circ} \mathrm{C}$ (Freeman and Zucker, 2000). These studies indicate that even though core body temperature is considered a homeostatic trait, there is genetic variability.

Heat Loss and Feed Intake Differences Explained by Activity. After accounting for the effects of line and sex, the regression of heat loss $\left(\mathrm{kcal} / \mathrm{kg}^{0.75} / \mathrm{d}\right)$ on log base 2 activity was $7.926(P<0.01)$, and the regression of feed intake $\left(\mathrm{g} / \mathrm{kg}^{0.75} / \mathrm{d}\right)$ was $4.109(P<0.001)$. Using the data reported at Generation 15 (Nielsen et al., 1997a,b; heat loss: $\mathrm{MH}=179.1$ and $\mathrm{ML}=107.5 \mathrm{kcal} / \mathrm{kg}^{0.75} / \mathrm{d}$; feed intake: $\mathrm{MH}=62.7$ and $\mathrm{ML}=50.9 \mathrm{~g} / \mathrm{kg}^{0.75} / \mathrm{d}$ ), the difference between $\mathrm{MH}$ and ML for heat loss was $71.6 \mathrm{kcal} /$ $\mathrm{kg}^{0.75} / \mathrm{d}$ and for feed intake was $11.8 \mathrm{~g} / \mathrm{kg}^{0.75} / \mathrm{d}$. Given the difference between $\mathrm{MH}$ and $\mathrm{ML}$ in log base 2 activity 




Time (hour)

Figure 1. Mean locomotor activity during a 72-h period, beginning at 1000, for mice of the three heat-loss selection lines $(\mathrm{MH}=$ high, $\mathrm{ML}=$ low, and $\mathrm{MC}=$ control $)$.

$(\mathrm{MH}=8.268$ and $\mathrm{ML}=7.232$, Table 1$)$ of 1.036 , the product of the regression and the activity difference equals $4.26 \mathrm{~g} / \mathrm{kg}^{0.75} / \mathrm{d}$ for feed intake and $8.21 \mathrm{kcal} / \mathrm{kg}^{0.75} /$ $\mathrm{d}$ for heat loss. Thus, $11.5 \%$ (8.21/71.6) of the difference between $\mathrm{MH}$ and ML for heat loss and 36\% (4.26/11.8) of the difference for feed intake are explained by the difference in physical activity.

As noted by Nielsen et al. (1997a), care must be exercised in trying to equate heat loss as measured in this study with energy for maintenance or feed intake. Mature, nonlactating animals were used in this work. Thus, one would expect heat production, and hence heat loss in the long run, to be similar to energy utilized for maintenance. But the measurement of heat loss in this study, which worked well as a selection criterion, is evidently not the same as energy metabolized for dayto-day maintenance. Mice were accustomed to being caged in a group and continuously on bedding. In the

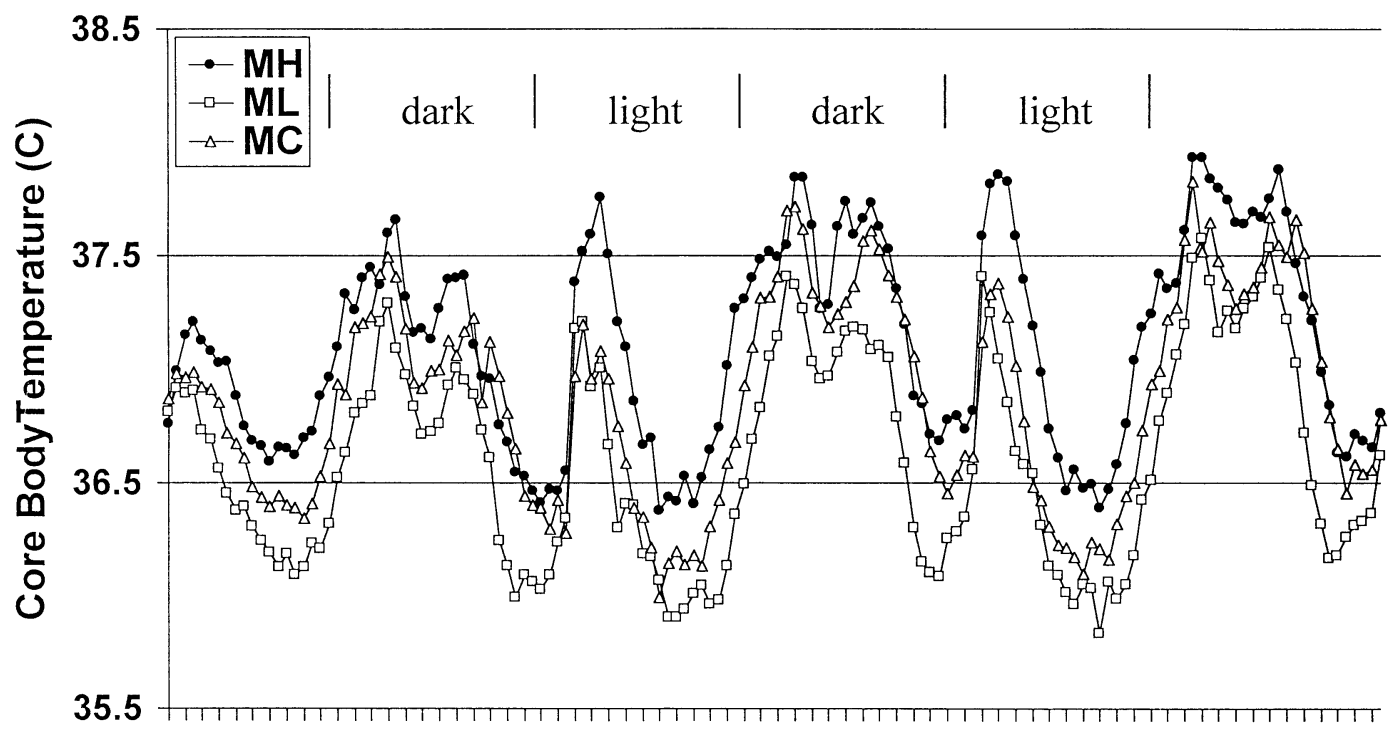

Time (hour)

Figure 2. Mean core body temperature during a 72-h period, beginning at 1000, for mice of the three heat-loss selection lines $(\mathrm{MH}=$ high, $\mathrm{ML}=$ low, and $\mathrm{MC}=$ control $)$. 


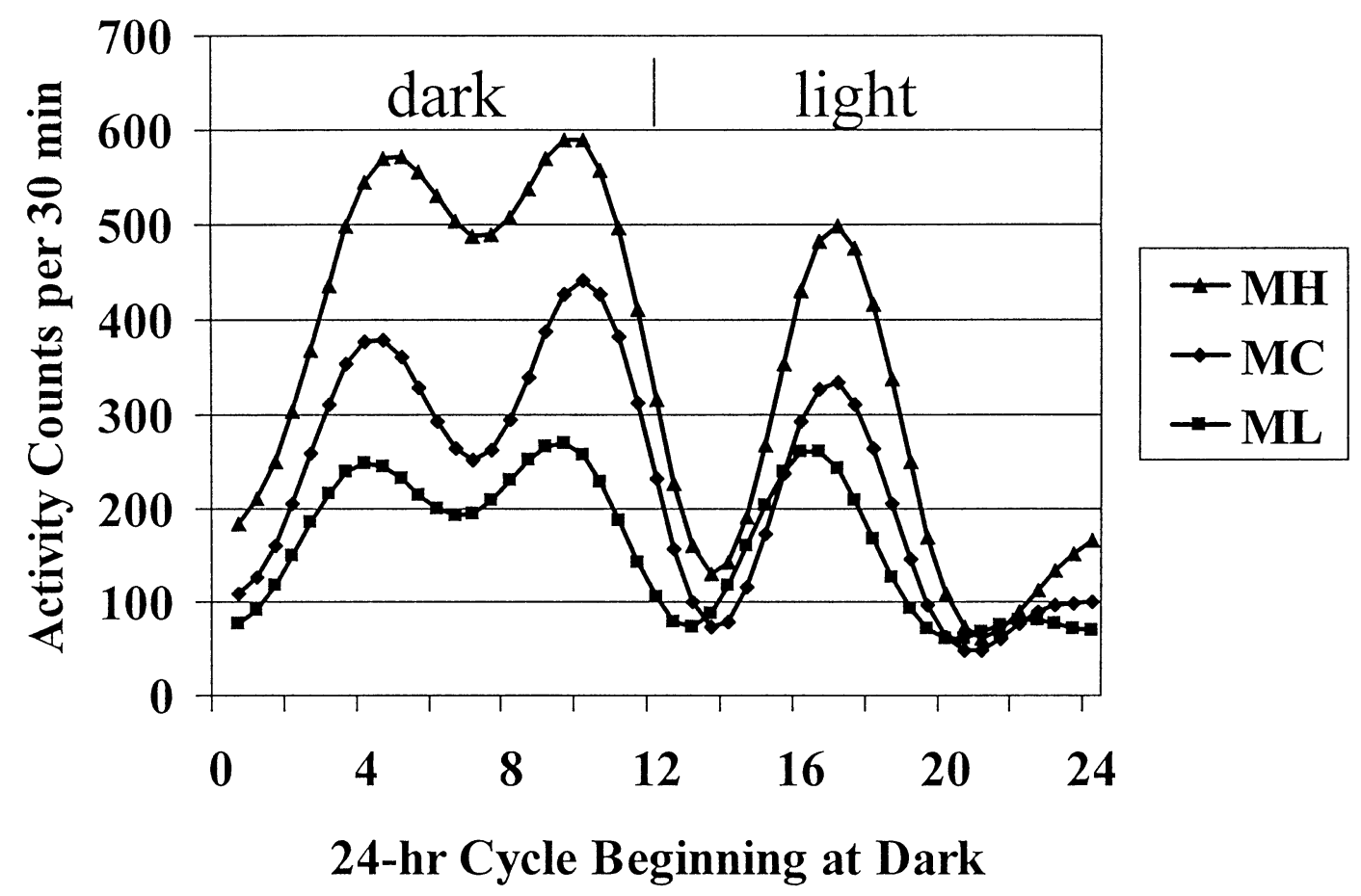

Figure 3. Predicted locomotor activity using a Fourier series model during a 24-h period, beginning at dark, for mice of the three heat-loss selection lines $(\mathrm{MH}=$ high, $\mathrm{ML}=$ low, and $\mathrm{MC}=$ control).

calorimeters, individual animals were placed in bare stainless steel cages and some were thus much more active and gave off much more heat, magnifying the difference between animals. Under more "usual" dayto-day conditions for the animals, one might expect that the difference between selection lines in physical activ- ity is explaining about $35 \%$ of the difference in heat loss (i.e., the same as for feed intake).

\section{Implications}

Selection to change heat loss or feed energy intake also changes level of locomotor activity. Whether one

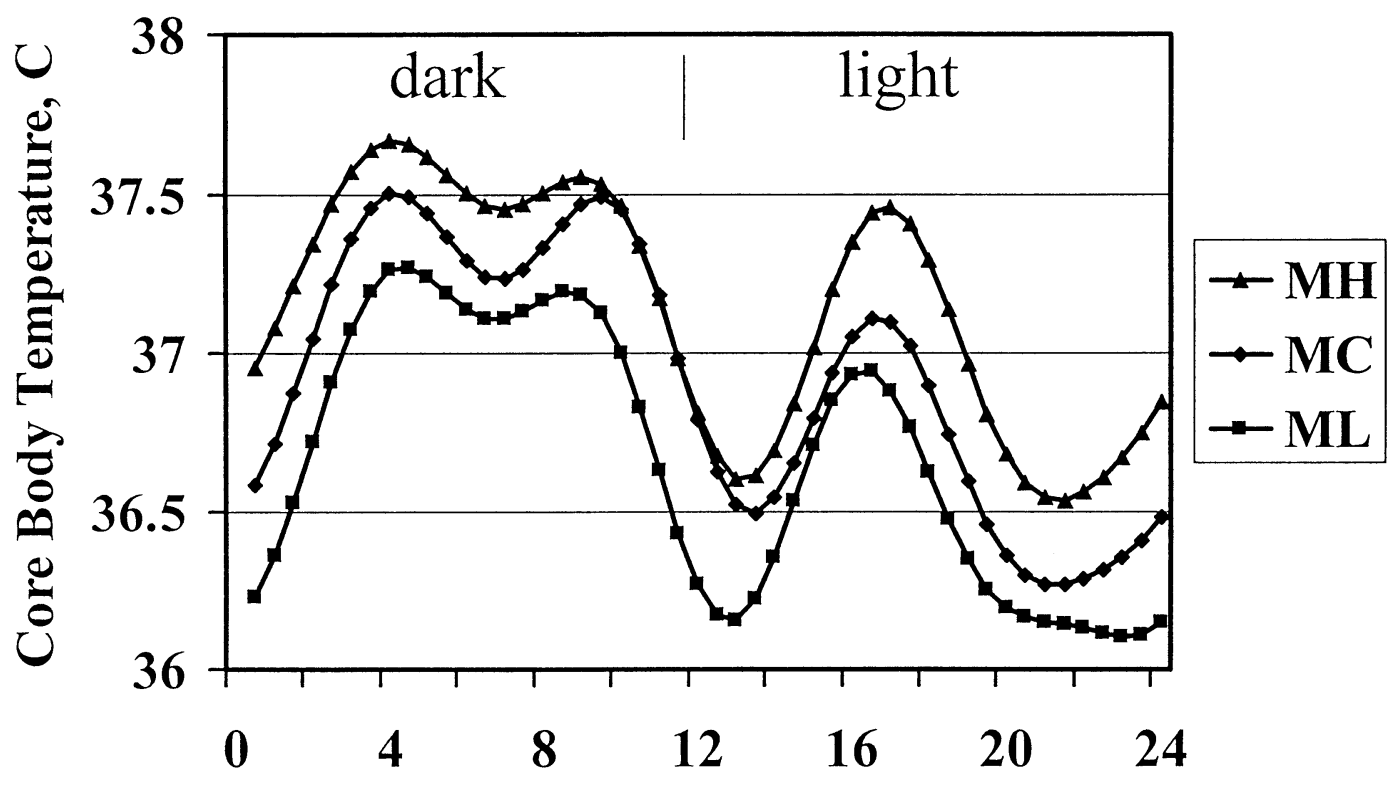

\section{4-hr Cycle Beginning at Dark}

Figure 4. Predicted body temperature using a Fourier series model during a 24-h period, beginning at dark, for mice of the three heat-loss selection lines $(\mathrm{MH}=$ high, $\mathrm{ML}=$ low, and $\mathrm{MC}=$ control). 
can practice selection on level of physical activity to change feed requirement for maintenance is not known. Part of physical activity is wasted energy and can be reduced.

\section{Literature Cited}

Bunger, L., M. D. MacLeod, C. A. Wallace, and W. G. Hill. 1998. Direct and correlated effects of selection for food intake corrected for body weight in the adult mouse. In: Proc. 6th World Cong. on Genet. Appl. to Livest. Prod. Armidale, NSW, Australia. 26:97-100.

Castella, J., and M. Alemany. 1985. Sex differences in the thermogenic response of the rat to a "cafeteria" diet. IRCS (Int. Res. Commun. Syst.) Med. Sci. 13:586-587.

Connolly, M. S., and C. B. Lynch. 1983. Classical genetic analysis of circadian body temperature rhythms in mice. Behav. Genet. 13:491-500.

Daucey, M. J. 1986. Activity-induced thermogenesis in lean and genetically obese (ob/ob) mice. Experiemtia (Basel) 42:547-549.

Doi, K., and A. Kuroshima. 1982. Sexual difference in thermoregulatory ability of rats exposed to cold and heat. J. Therm. Biol. 7:99-106.

Freeman, D. A., and I. Zucker. 2000. Temperature-independent circannual variation in circadian rhythms of golden-mantled ground squirrels. J. Biol. Rhythms. 15:336-343.

Gordon, C. J. 1993. Temperature Regulation in Laboratory Rodents pp 85, 87, 112, 130. Cambridge University Press, Cambridge, MA.

Halter, H. M., C. Wenk, and A. Schurch. 1980. Effect of feeding level and feed composition on energy utilization, physical activity and growth performance of piglets. In: L. E. Mount (Ed.) Proc. 8th Symp. Energy on Metabolism. Churchill College, Cambridge. EAAP 26:395-398.

Henken, A. M., W. van der Hel, H. A. Brandsma, and M. W. A. Verstegen. 1991. Differences in energy metabolism and protein retention of limit-fed growing pigs of several breeds. J. Anim. Sci. 69:1443-1453.

Hiddinga, A. E., D. G. M. Beersma, and R. H. Van Den Hooffdakken. 1997. Endogenous and exogenous and components in the circadian variation of core body temperature in humans. J. Sleep Res. 6:156-163.

Honma, H., and T. Hiroshige. 1978. Simultaneous determination of circadian rhythms of locomotor activity and body temperature in the rat. Jpn. J. Physiol. 28:159-169.

Krauchi, K., and A. Wirz-Justice. 1994. Circadian rhythm of heat production, heart rate, and skin and core temperature under unmasking conditions in men. Am. J. Physiol. 267:R819- R829.

Luiting, P., J. W. Schrama, W. van der Hel, E. M. Urff, P. G. J. J. van Boekholt, E. M. W. van den Elsen, and M. W. A. Verstegen. 1991. Metabolic differences between white leghorns selected for high and low residual feed consumption. In: C. Wenk and M. Boessinger (Ed.) Proc. 12th Symp. on Energy Metabolism. Eur. Assoc. Anim. Prod. Karatuse Ittingen, Switzerland. 58:384-387.

MacLeod, M. G., T. R. Jewitt, J. White, M. Verbrugge, and M. A. Mitchell. 1982. The contribution of locomotor activity to energy expenditure in the domestic fowl. In: A. Ekern and F. Sundstol (ed.) Proc. 9th Symp. Energy on Metabolism. Eur. Assoc. Anim. Prod. Lillehammer, Norway. 29:297-300.

McDonald, R. B., D. Day, K. Carlson, J. S. Stern, and B. A. Horwitz. 1989. Effect of age and gender on thermoregulation. Am. J. Physiol. 257:R700-R704.

Milligan, L. P. 1985. Discussion section: metabolic components of energy expenditure introductory comments. In: P.W. Moe, H. F. Tyrrell, and P. J. Reynolds (ed.) Proc. 10th Symp. Energy on Metabolism. Eur. Assoc. Anim. Prod. Airlie, Virginia 32:66-67.

Moody, D. E., D. Pomp, and M. K. Nielsen. 1997. Variability in metabolic rate, feed intake and fatness among selection and inbred lines of mice. Genet. Res. 70:225-235.

Moruppa, S. M. 1990. Energy expenditure and locomotor activity in mice selected for food intake adjusted for body weight. Theor. Appl. Genet. 79:131-136.

Nielsen, M. K., B. A. Freking, L. D. Jones, S. M. Nelson, T. L. Vorderstrasse, and B. A. Hussey. 1997a. Divergent selection for heat loss in mice: II. Correlated responses in feed intake, body mass, body composition, and number born through fifteen generations. J. Anim. Sci. 75:1469-1476.

Nielsen, M. K., L. D. Jones, B. A. Freking, and J. A. DeShazer. 1997b. Divergent selection for heat loss in mice: I. Selection applied and direct response through fifteen generations. J. Anim. Sci. 75:1461-1468.

Nienaber, J. A., Y. R. Chen, and G. L. Hahn. 1985. Energetics of activity using indirect calorimetry. In: P.W. Moe, H. F. Tyrrell, and P. J. Reynolds (ed.) Proc. 10th Symp. Energy on Metabolism. Eur. Assoc. Anim. Prod. Airlie, Virginia. 32:164-167.

Rauw, W. M., P. Luiting, M. Bakken, T. Schuurman, C. J. M. de Veer, and O. Vangen. 2000. Behavioral differences in non-reproductive adult females in a long-term selection experiment for litter size in mice. Appl. Anim. Behav. Sci. 66:249-262.

Refinetti, R., and M. Menaker. 1992. The circadian rhythm of body temperature. Physiol. Behav. 51:613-637.

Strickland, J. L., J. L Miner, and M. K. Nielsen. 1998. Feed intake, thyroid hormones and adrenergic stimulation in high and low heat loss mice. J. Anim. Sci. 76 (Suppl. 2):41 (Abstr.).

Toth, L. A., J. E. Rehg, and R. G. Webster. 1995. Strain differences in sleep and other pathophysiological sequelae of influenza virus infection in naive and immunized mice. J. Neuroimmunol. 58:89-99.

Verstegen, M. W. A., W. van der Hel, H. A. Brandsma, and E. Kanis. 1982. Heat production of groups of growing pigs as affected by weight and feeding level. In: A. Ekern and F. Sundstol (ed.) Proc. 9th Symp. Energy on Metabolism. Eur. Assoc. Anim. Prod. Lillehammer, Norway. 29:218-221.

Voisinet, B. D., T. Grandin, J. D. Tatum, S. F. O'Connor, and J. J. Struthers. 1997. Feedlot cattle with calm temperaments have higher average daily gains than cattle with excitable temperaments. J. Anim. Sci. 75:892-896.

Yanase, M., H. Tanaka, and T. Nakayama. 1989. Effects of estrous cycle on thermoregulatory responses during exercise in rats. Eur. J. Appl. Physiol. Occup. Physiol. 58:446-451.

Yunis, E. J., G. Fernandes, W. Nelson, and F. Halberg. 1974. Circadian temperature rhythm and aging in rodents. In: L. E. Scheving, F. Halberg and J. E. Pauly (ed.) Chronobiology. pp 358363, Igaku Shoin, Tokyo. 